\title{
THE SULPHONAMIDES IN THE TREATMENT OF INFECTIONS IN INFANCY
}

\author{
BY \\ M. HENDERSON, M.B., Ch.B., D.C.H. \\ Senior Resident Medical Officer, Alder Hey Children's Hospital, Liverpool \\ and \\ E. C. R. COUPER, M.D., F.R.F.P.S., D.P.H. \\ Deputy Medical Superintendent, Walton Hospital, Liverpool
}

\begin{abstract}
Although there is now a considerable literature dealing with the use of sulphonamides in many diseases, there are few articles on their use in infancy. Some authors, e.g. Leathart (1943), Field et al. (1943), Patterson and Stewart Smith (1944), mention, sometimes in a rather unenthusiastic manner, that sulphonamides were given but supply no details. The material of present study consists of 415 infants under the age of ten months who suffered from some infection and were, for the most part, treated with one of the sulphonamide group of drugs. An attempt has been made to assess the value of these drugs in such infections. Meningococcal meningitis and gonorrhoeal ophthalmia have not been included. The cases were treated in Alder Hey Childrens' Hospital, Liverpool, which deals with approximately 1000 infants per annum and in Walton Hospital, Liverpool, which has a large maternity department. The latter department dealt with 3700 confinements in 1943 and one part of this investigation was made possible by the unfortunate occurrence of an outbreak of neonatal gastroenteritis.
\end{abstract}

Scheme of treatment. In order to standardize treatment in the two hospitals it was decided to employ the following doses by mouth: for mature infants, an initial dose of $0.75 \mathrm{gm}$. to $1.0 \mathrm{gm}$., followed by $0.5 \mathrm{gm}$. four-hourly; and for premature infants an initial dose of $0.5 \mathrm{gm}$. followed by $0.25 \mathrm{gm}$. three-hourly. This is the system of dosage advocated by Henderson (1943) for sulphaguanidine. Glucose-saline was given in the early stages of the illness to assist in the elimination of the drug and to overcome dehydration if present. In more severely dehydrated infants continuous intravenous drip salines were administered as required. It was also decided to use the drugs as far as possible according to the following system:

A. Neonates - up to one month. (a) Premature. (b) Mature.

B. Infants-from one to nine months. These groups were then subdivided as follows:

(1) ENTERAL INFECTIONS, i.e. where no evidence

of parenteral infection could be found : (a) Neonatal gastroenteritis Sulphaguanidine.

(b) Gastroenteritis in older infants

(2) Parenteral infections.

(a) Bronchopneumonia Sulphapyridine. Pneumonia. Sulphasuxidine.

No chemotherapy.

(b) Nasopharyngitis. Bronchitis.

Sulphathiazole.

Sulphadiazine.

Sulphamezathine.

Sulphapyridine.

Sulphathiazole.

Sulphadiazine.

Sulphamezathine.

(c) Otitis media. Mastoiditis.

Sulphapyridine.

Sulphathiazole.

Sulphadiazine.

Sulphamezathine.

(d) Pyelitis.

Sulphapyridine.

Sulphathiazole.

Sulphadiazine.

Sulphamezathine.

(e) Skin sepsis.

Sulphathiazole.

Sulphadiazine.

Sulphonamidecream.

Classification of results. The classification of the results of an investigation such as this is a difficult problem. Three methods suggest themselves.

(1) BACTERIOlogical. Bacteriological classification would obviously be the most satisfactory method. Unfortunately bacteriology in infantile infections is inconclusive and therefore does not commend itself as a basis of classification. For example, the bacteriology of the faeces in cases coming under the title of ' gastroenteritis' is highly unsatisfactory; swabs from discharging ears almost invariably give a mixed growth; specimens of urine are often difficult to obtain and in pneumonia bacteriological investigations are not practicable.

(2) Clinical. Classification according to disease is a suitable method as far as it goes. Unfortunately its success depends upon individual interpretation of clinical signs, which is notoriously difificult in infancy. Certain infections are much less common than others and even when cases are grouped together the numbers are too small to be of statistical significance. 
(3) ACCORDING TO THE DRUG USED. This method is also unsatisfactory because the sulphonamides have no clearly defined specificity and equal results may be obtained in the same type of infection with different drugs.

The bacteriological method of classification being out of the question, the present series has been subdivided on a plan which includes the second and third methods, i.e. by a classification based on the clinical findings and the sulphonamide drug used.

\section{Part I}

\section{(1) Enteral infections}

(a) Neonatal gastroenteritis. All the cases in this group fell within the neonatal period and consisted of babies showing signs of gastroenteritis for which no parenteral cause could be found on careful clinical examination. Two sulphonamide drugs were used, sulphaguanidine and sulphasuxidine, and a small group were treated without sulphonamide. There are 128 cases in the whole group, 57 treated with sulphaguanidine, 52 treated with sulphasuxidine and 19 had no sulphonamide.

\section{SUlPHAGUANIDINE}

General figures. Of the 57 cases, ten died (17.5 per cent.). There were 34 males and 23 females. Using the standard of $5 \frac{1}{2} \mathrm{lb}$. birth weight, there were nine premature infants and 48 mature infants. Of the nine premature infants four died ( 44.4 per cent.) and six (12.5 per cent.) of the mature infants died. Two cases had two attacks and one of them died at the age of four months.

Symptoms. Date of onset. The disease began between four and 24 days after birth (average 10.7 days).

Diarrhoea. Every case had diarrhoea and in twelve the diarrhoea was severe.

Vomiting. The majority had vomiting, but in seventeen there was no vomiting.

Dehydration. In eighteen there was no dehydration, thirty had mild dehydration and nine were considerably dehydrated.

Pyrexia. Thirty were apyrexial throughout and 27 were pyrexial in varying degree. The temperature varied from $99^{\circ} \mathrm{F}$ to $104 \cdot 8^{\circ} \mathrm{F}$.

Weight loss. Every case suffered some weight loss. This varied from 3 to $26 \mathrm{oz}$. (average $10 \mathrm{oz}$.).

GeNERAL ASSESSMENT. Severe, 13 (death rate 61.5 per cent.); moderate, 16 ; mild, 28.

Among the mild cases two died, one some months later and the other, a premature infant, died eleven days after recovering from the gastroenteritis. These two cases might reasonably be deducted from the deaths and in that case the death rate would be 14 per cent. None of the moderate group died and the remainder of the deaths were severe examples.

PROGReSS OF THE DISEASE. Duration of pyrexia. Eighteen cases were pyrexial for only one day after the drug was begun, although some had been pyrexial for four to seven days previously. In two of the deaths the temperature was uncontrolled. Five patients who died were apyrexial throughout and two were apyrexial in one day.

Stools. In those who recovered stools became normal in one to ten days (average 3.2 days).

Weight. Weight lost as a result of the illness was regained in 36 cases in periods varying from three to twenty-four days (average $12 \cdot 9$ days). Eleven patients were removed from hospital against advice and their subsequent history is not known.

BACTERIOLOGY. Faeces were examined in fifteen cases, with negative result in eleven cases. In four cases B. Morgan I, usually regarded as nonpathogenic, was grown.

DOSE OF THE DRUG. Those of the mature infants who recovered received doses ranging from $3.75 \mathrm{gm}$. to $27.25 \mathrm{gm}$. (average $12.8 \mathrm{gm}$.). In the case of premature infants the total dose varied from $1.25 \mathrm{gm}$. to $8.25 \mathrm{gm}$. (average $4.8 \mathrm{gm}$.).

COMPLICATIONS OF THE DRUG. One patient developed a macular rash and three developed oedema of legs and lower abdomen. These three cases had respectively a total dose of $14.25 \mathrm{gm} ., 12 \mathrm{gm}$. and $16.25 \mathrm{gm}$. of the drug. Two were unfortunately taken from hospital against advice and their ultimate fate is unknown. The third case died and the suspicion that the oedema might be due to renal damage was not confirmed at post-mortem examination.

COMPLiCATIONS OF THE ILLNESS. One had continued pyrexia and developed signs of bronchitis, but ultimately recovered. In another the left ear began to discharge five days after the onset of the diarrhoea which was almost certainly parenteral in origin. Another developed right acute otitis media some weeks afterwards and ultimately died. Three had conjunctivitis and one mild jaundice. One had a congenital haemangioma of the left arm and wrist drop.

PoST-MORTEM FINDINGS. Two of the deaths took place three months and eleven days respectively after recovery from the attack of enteritis. In the first of these bronchopneumonia and right acute otitis media were found at post-mortem examination; and in the second, which was $3 \mathrm{lb} .10 \mathrm{oz}$. at birth, no cause other than prematurity was found. In a third case permission for examination was refused. Of the seven remaining cases five had bronchopneumonia, accompanied in one case by bilateral acute otitis media which did not seem to be a secondary occurrence. The sixth case was a premature infant of $4 \mathrm{lb} .1 \mathrm{oz}$. at birth, which was found to have right acute otitis media. The seventh case was the one which became oedematous. This infant had been very ill from the outset and was found to have right acute otitis media, left empyema, and pus in the right sternoclavicular joint, the organism being a staphylococcus. Section of the kidney showed no evidence of blockage by crystalline deposits of the sulphonamide.

\section{SULPHASUXIDINE}

General figures. Of the 52 cases, eleven died $(21 \cdot 1$ per cent.). There were 28 males and 24 females; ten were premature infants and $\mathbf{4 2}$ mature infants. Of the ten premature infants six died (60 per cent.) and five (11.9 per cent.) of the mature infants died. Two patients had two attacks.

Symproms. Date of onset. All fell within the neonatal period and the disease began between four to twenty-eight days after birth (average $11 \cdot 9$ days).

Diarrhoea. With one exception every case had diarrhoea and in two it was severe.

Vomiting. In 26 cases there was no vomiting.

Dehydration. In 21 cases there was no dehydration, while 26 had mild dehydration and five severe dehydration. 
Pyrexia. Twenty-six were apyrexial and 26 were pyrexial in varying degree, the temperature varying at its maximum from $99^{\circ} \mathrm{F}$. to $105 \cdot 4^{\circ} \mathrm{F}$.

Weight loss. With the exception of two cases in whom weight remained stationary, every case lost some weight, varying from 4 to $24 \mathrm{oz}$. (average 10 oz.).

GeNERAL ASSESSMENT. Severe, 15 (death rate 66.6 per cent.); moderate, 19 ; mild, 19.

Among the mild cases there were no deaths. One death occurred in the moderate group, a premature infant which developed cyanotic attacks due to bronchopneumonia a fortnight later. If this death is not included, the mortality rate falls to $19 \cdot 2$ per cent. The remainder of the deaths were severe cases.

Progress of THE DISEASE. Duration of pyrexia. Twenty infants were pyrexial for only one day after giving the drug. One infant was pyrexial for twelve days and one infant who died was uncontrolled. Seven of those who died were apyrexial throughout. Of the remaining fatal illnesses, two were pyrexial for one day and one for three days.

Stools. Stools became normal in those who recovered in one to seven days (average 3.3 days).

Weight. Weight lost as a result of the illness was regained in 36 cases in periods varying from four to thirty days (average 14.3 days). In four cases the after-history is not known as they were taken from hospital against advice.

BACTERIOLOGY. Stools were examined in 31 cases, with negative result in 27 . Four grew $B$. Morgan I. Three were examined twice with negative result and in three the urine was also negative.

DOSE OF THE DRUG. Of the mature infants who recovered and had a full course, the total dose varied from $6 \cdot 25 \mathrm{gm}$. to $20 \cdot 75 \mathrm{gm}$. (average $12.6 \mathrm{gm}$.). In the case of premature infants the total dose varied from $6.5 \mathrm{gm}$. to $10.75 \mathrm{gm}$. (average $9.3 \mathrm{gm}$.).

COMPLICATIONS OF THE DRUG. One case developed haematuria and the drug was instantly stopped. Kapilon was given and no further trouble ensued. Another developed slight oedema of the legs which resolved satisfactorily.

COMPLICATIONS OF THE ILLNESS. In three cases, soon after the onset of the enteritis, symptoms of parenteral infection which was the probable cause of the illness, became apparent: one, pneumonia; one, nasopharyngitis; and one, otitis media and bronchitis. One had had bronchitis ten days previously. As already mentioned, one premature infant had a cyanotic attack in which it died. Three were jaundiced and one was a case of erythroblastosis foetalis. Six developed mild thrush and one had congenital heart disease.

Post-MORTEM FINDINGS. Permission for postmortem examination was obtained in eight cases. The premature infant with the cyanotic attack had bronchopneumonia. In the seven remaining cases all save one showed evidence of parenteral infection as follows: two with bronchitis and otitis media, two with bronchitis alone, one with bronchitis and prematurity and one with bronchopneumonia and otitis media.

\section{No Chemotherapy}

General figures. Of the nineteen cases, five died (26.3 per cent.). There were eleven males and eight females, among whom were nine premature infants and ten mature infants. Of the nine premature infants, four died ( 44.4 per cent.) and one of the mature infants died (10 per cent.).

Symptoms. Date of onset. All began within the neonatal period between 6 to 28 days after birth (average 13.4 days).

Diarrhoea. All but three had diarrhoea. Two of those without diarrhoea died.

Vomiting. Eight cases had vomiting, one severely.

Dehydration. Ten were dehydrated but none severely.

Pyrexia. Ten cases were apyrexial and seven were pyrexial, temperature varying from $99 \cdot 2 \mathrm{~F}$. to $101 \cdot 6^{\circ} \mathrm{F}$. In two cases there is unfortunately no record.

Weight. Sixteen cases lost weight in amounts varying from 5 to $24 \mathrm{oz}$. (average 10.9 oz.). In three cases weight remained stationary.

General ASSESSMENT. Severe, 6 (death rate 83.3 per cent.); moderate, 5 ; mild, 8 .

There were no deaths in the mild or moderate groups.

Progress OF THE DISEASE. Duration of pyrexia. Four cases were pyrexial for one day after commencing treatment, three were pyrexial for two to ten days and ten were apyrexial throughout. Three of the infants who died did not have pyrexia and one was pyrexial for five days. In one fatal case the temperature is not known.

Stools. The stools became normal in those who recovered in two to seven days (average 3.4 days).

Weight. Weight lost as a result of the illness was regained in seven cases in periods varying from 8 to 19 days (average 11.7 days). Seven cases were removed from hospital against advice.

COMPLiCATIONS OF THE ILLNESS. Five had mild thrush, three were jaundiced and two were thought to have developed bronchopneumonia.

POST-MORTEM FINDINGS. Permission for postmortem examination was obtained in four of the five fatal cases. The results are as follows: one, bronchitis; one, bronchopneumonia and bilateral acute otitis media; one, bilateral acute otitis media. In the fourth case prematurity was the only cause of death found.

\section{Comment}

TABLE I

\begin{tabular}{|c|c|c|c|c|c|c|}
\hline & \multicolumn{2}{|c|}{$\begin{array}{l}\text { Sulpha- } \\
\text { guanidine } \\
57 \text { cases }\end{array}$} & \multicolumn{2}{|c|}{$\begin{array}{l}\text { Sulpha- } \\
\text { suxidine } \\
52 \text { cases }\end{array}$} & \multicolumn{2}{|c|}{$\begin{array}{c}\text { No chemo- } \\
\text { therapy } \\
19 \text { cases }\end{array}$} \\
\hline & No. & Per cent. & No. & Per cent. & No. & Per cent \\
\hline $\begin{array}{l}\text { Premature } \\
\text { Mature } \quad .\end{array}$ & $\begin{array}{r}9 \\
48\end{array}$ & $\begin{array}{l}15 \cdot 7 \\
84 \cdot 3\end{array}$ & $\begin{array}{l}10 \\
42\end{array}$ & $\begin{array}{l}19 \cdot 2 \\
80 \cdot 8\end{array}$ & $\begin{array}{r}9 \\
10\end{array}$ & $\begin{array}{l}47 \cdot 3 \\
52 \cdot 7\end{array}$ \\
\hline $\begin{array}{l}\text { Mild . } \\
\text { Moderate.. } \\
\text { Severe } \quad .\end{array}$ & $\begin{array}{l}28 \\
16 \\
13\end{array}$ & $\begin{array}{l}49 \cdot 1 \\
28 \cdot 0 \\
22 \cdot 8\end{array}$ & $\begin{array}{l}19 \\
18 \\
15\end{array}$ & $\begin{array}{l}36 \cdot 5 \\
34 \cdot 6 \\
28 \cdot 8\end{array}$ & $\begin{array}{l}8 \\
5 \\
6\end{array}$ & $\begin{array}{l}42 \cdot 1 \\
26 \cdot 3 \\
31 \cdot 3\end{array}$ \\
\hline Deaths & 10 & $17 \cdot 5$ & 11 & $21 \cdot 1$ & 5 & $26 \cdot 3$ \\
\hline
\end{tabular}

It will be seen from the comparative table (table I) that of the first two groups the sulphasuxidine group is probably the more severe. The group with no chemotherapy is the most severe owing to the high proportion of premature infants and this group has 
the highest death rate. The relatively small difference in the mortality rates between the drugtreated and the non-drug-treated groups should be noted.

The rationale of using these sulphonamide drugs lies in the fact that they are poorly absorbed from the intestinal tract. Approximately two-thirds of sulphaguanidine are absorbed while one-third is excreted in the faeces in high concentration. Only 5 per cent. of sulphasuxidine is absorbed (M.R.C. War Memorandum No. 10). Drugs acting in this way might be expected to operate against an infection of the gastrointestinal tract and of the two sulphasuxidine should be the better. Other workers have found that these drugs exert a good effect in the dysentery group of diseases but in neonatal gastroenteritis no satisfactory bacteriological explanation in the faeces has been forthcoming. The results in the sulphasuxidine group are not materially better than those in the sulphaguanidine group. The post-mortem findings in the present series show the presence of parenteral infection in the great majority of cases; such infection is not likely to be benefited by the usual mode of action of these sulphonamides, though possibly the portion of the drug absorbed is responsible to some extent for the recoveries. The parenteral infections found are in no way different from those often found in older infants suffering from gastroenteritis and the belief is growing that there is no essential difference between the so-called neonatal gastroenteritis and the gastroenteritis of older infants. This view has recently been expressed by Burns and Gunn (1944). On the other hand, MacGregor (1939), describing her experience of neonatal pneumonia, found that in the neonatal period organisms of the colon bacillus group and staphylococcus aureus were the commonest responsible pathogens. She also states that coliform infections are confined to the neonatal period. It is possible then that drugs such as sulphaguanidine and sulphasuxidine which reduce the number of enteral coliform organisms, may also exert an effect in parenteral infections of the type found at post-mortem examination in the present series.

Some of the recorded figures are interesting. The death rate in an outbreak described by Craig (1936) was 26.8 per cent. In three outbreaks described by Ormiston (1941) the following were the figures.

$\begin{array}{lccc} & & \text { Total DEATH } & \begin{array}{c}\text { DEATH RATE } \\ \text { IN SERIOUS } \\ \text { RATE } \\ \text { PER CENT. }\end{array} \\ \text { Outbreak A } & \ldots & 18 \cdot 5 & \text { PER CENT. } \\ \text { Outbreak B } & \ldots & 30 \cdot 1 & 62 \\ \text { Outbreak C } & \ldots & 38 \cdot 0 & 81 \\ \end{array}$

In outbreak $\mathrm{C}$ sulphathiazole and sulphapyridine were tried without benefit. In the present series the total death rates in the three groups are 14, 19.2 and 26.3 per cent. respectively while among the severe cases the corresponding figures are $61 \cdot 5$, 66.6 and 83.3 per cent. If these figures are compared it will be seen that in the drug-treated groups the total death rates are slightly lower than in Ormiston's series but in the severe cases the death rates are uninfluenced. Henderson (1943) gives his figures before and after the use of sulphaguanidine. Before sulphaguanidine the death rate varied from 14 to 31 per cent. and after, it was 10 per cent. and he speaks very highly of this treatment. Collis (1943) reports cure in two-thirds of cases by the use of sulphaguanidine whereas McSweeney (1942) reports no material benefit. The latter states that 50 per cent. of those treated with sulphaguanidine died and 38.2 per cent. of those not so treated died. There are few references to the use of sulphasuxidine. Twyman and Horton (1943) report favourable results. Of 22 cases of neonatal diarrhoea, eleven were treated with sulphasuxidine with two deaths, due in their opinion to inadequate dosage, whilst there were four deaths in the control group and 'weight gains for eight days of infants treated with succinyl-sulphathiazole were not matched in seventeen days by the untreated infants.' They recommend the administration of vitamin $K$ to infants treated with this drug because the reduction of the coliform organisms caused by the drug inhibits the absorption of the vitamin and promotes bleeding tendencies. Certainly the baby in the present series who developed haematuria seemed to benefit by the use of vitamin K. In Gunn's (1943) 22 severely dehydrated cases, the case fatality was 45.5 per cent. and he reports little effect from the drug. He also reports no benefit from sulphaguanidine. Lewes (1943) reports a case, ultimately found to have bilateral mastoiditis, in which two courses of sulphasuxidine had no effect.

The views on this matter are therefore conflicting, possibly due to some epidemiological difference in the outbreaks described. From the present series it would seem that the total death rate can be reduced to some extent but the treatment must be begun as soon as possible since in severely affected infants these drugs appear to exert little benefit.

\section{(1) Enteral infections}

(b) Gastroenteritis in older infants. In this group there are 24 cases and again the drugs employed are sulphaguanidine and sulphasuxidine. The group also contains a number who had no chemotherapy. The group displayed the following symptoms:-24 had diarrhoea, 22 vomiting and 21 dehydration. Thirteen were pyrexial and eleven were apyrexial throughout. Loss of weight occurred in every case.

\section{SulPhaguanidine}

General figures. There were eight cases, five males and three females of whom two were premature infants. No deaths occurred.

General ASSESSMENT. Severe, 7 ; mild, 1.

Progress of THE disease. Duration of pyrexia. In four cases temperature lasted for 24 hours and in two cases for two days. The remainder were apyrexial throughout.

Stools. The stools became normal in two to nine days (average 5 days).

Dehydration. This was severe in six cases and four required intravenous fluids.

Weight. All gained weight except one which was taken from hospital against advice.

BACTERIOLOGY. Faeces were examined in five cases with negative results.

TOTAL DOSE OF THE DRUG. For the mature infants the average total dose was $19 \mathrm{gm}$. and for the premature infants $8.25 \mathrm{gm}$. No complications of the drug were observed.

COMPLICATIONS OF THE ILlNESS. One case had 
congenital heart disease and congenital corneal opacities.

\section{SULPHASUXIDINE}

General FIGURES. There were seven cases, three males and four females. All were mature infants and no deaths occurred.

GenERAL ASSESSMENT. Severe, 1; moderate, 3; mild, 3.

Progress OF THE DISEASE. Duration of pyrexia. Three were pyrexial for one, two and four days respectively. The remainder were apyrexial throughout.

Stools. The stools became normal in one to seventeen days (average $4 \cdot 5$ days).

Dehydration. Only in one case was dehydration sufficiently severe to necessitate intravenous fluids.

Weight. All made satisfactory gain in weight.

BACTERIOLOGY Faeces were examined in six cases with negative result.

TOTAL DOSE OF THE DRUG. The average total dose of the drug was $16 \mathrm{gm}$. and no complications were observed.

COMPLICATIONS OF the ILLNESS. One case developed right acute otitis media about the sixteenth day in hospital which responded to sulphathiazole, and glycerin and carbolic acid drops.

\section{No CHEMOTHERAPY}

General Figures. There were nine cases, four males and five females, among whom was one premature infant. One death occurred.

General asSESSMENT. Severe, 5 with 1 death; moderate, 1 ; mild, 3 .

PROGRESS OF THE DISEASE. Duration of pyrexia. In those who were pyrexial temperature remained elevated for two to five days.

Stools. The stools became normal in one to twenty-three days (average six days).

Dehydration. This was severe in five cases and intravenous fluids were given.

Weight. All but the infant who died gained weight satisfactorily.

BACTERIOLOGY. Faeces were examined in all cases with negative result in eight. One grew $B$. Morgan No. 5.

COMPLICATIONS OF THE ILLNESS. Three infants developed otitis media, one on the eleventh day, one on the thirteenth day and one on the thirty-first day in hospital.

POST-MORTEM EXAMINATION was unfortunately refused.

\section{Comment}

This group of gastroenteritis in older infants is small chiefly owing to the difficulty of finding infants not manife 'ing some signs of parenteral infection. The sulphasuxidine group seems to be the mildest of the three. There is little difference in the results in the three groups and the impression has been gained that the essential and most urgent aspect of the treatment is adequate treatment of dehydration. Some of the cases gained weight while having the drugs but it is felt that this is due to overcoming the dehydration and not to any virtue of the drugs. The group is too small to allow of a valid pronouncement and further investigation of this type of case is required.

\section{Part II}

\section{(2) Parenteral infections}

(a) Pneumonia and bronchopneumonia. This group contains 97 cases and four sulphonamides were used, sulphamezathine, sulphathiazole, sulphadiazine and sulphapyridine. It is not necessary to describe in detail the symptoms which this group presented. The great majority (except some of the premature infants) had cough and dyspnoea. Diarrhoea occurred in 28 , vomiting in 29 , pyrexia in 83 and 14 were apyrexial.

\section{SULPHAMEZATHINE}

General Figures. There were 35 cases, 20 males and 15 females, among whom were eight premature infants and 27 mature infants. Thirty suffered from bronchopneumonia and five from pneumonia. Of the 35 cases, nine died $(28.5$ per cent.).

0 to 1 month, $14 ; 7$ deaths ( 50 per cent.).

1 to 9 months, 21 ; 2 deaths (9 per cent.).

GeNERAL ASSESSMENT. Severe, 23 with 9 deaths (39.1 per cent); moderate, 12 with no deaths.

PROGRESS OF THE DISEASE. Duration of pyrexia. In nine cases temperature was normal in 24 hours, six in 48 hours, five in 72 hours, one in four days, one in six days, one in ten days and one in seventeen days. In five pyrexia was uncontrolled.

Cough and dyspnoea. In seventeen marked improvement took place in 24 to 48 hours. In the nine fatal cases the dyspnoea was not relieved. Five of the older infants who had whooping-cough improved slowly and five who were extremely ill on admission took several days to settle.

Stools. In those who had diarrhoea and recovered, stools were normal in one to four days.

TOTAL DOSE OF THE DRUG. Average $14 \mathrm{gm}$.

COMPLICATIONS OF THE DRUG. Four cases in the neonatal group developed a mild cyanosis which was thought possibly due to the drug. This disappeared on stopping the drug and no other complications took place.

COMPLICATIONS OF THE ILLNESS. In the neonatal group there was one case of rhinitis, one of submaxillary abscess and one of mastitis. Among the older infants five had whooping-cough, three had otitis media on admission and two developed it while in hospital. One infant with lobar pneumonia developed extensive cavitation of the right lung which eventually resolved almost completely. Unfortunately he was removed against advice after eight weeks in hospital.

POST-MORTEM FINDINGS. Permission for postmortem examination was obtained in eight of the nine deaths. In six cases the presence of bronchopneumonia was confirmed. Of the remaining two, one was found to have bilateral acute otitis media and the other bilateral mastoiditis, in addition to bronchopneumonia.

\section{Sulphathiazole}

General figures. There were 28 cases, 21 males and seven females including three premature infants and 25 mature infants. Twenty-five suffered from bronchopneumonia and three from pneumonia. Of the 28 cases, 11 died ( $39 \cdot 2$ per cent.).

0 to 1 month, $10 ; 6$ deaths (60 per cent.).

1 to 9 months, $18 ; 5$ deaths $(27.7$ per cent.).

GeNERAL ASSESSMENT. Severe, 20 with 11 deaths (55 per cent.); moderate, 8 with no deaths. 
PROGRESS OF THE DISEASE. Duration of pyrexia. One was apyrexial throughout. One was pyrexial for one day, four for two days, three for three days, four for four days, one for five days, one for eight days, one for twelve days and one for 44 days. The latter had two courses of treatment and ultimately recovered. In eleven cases temperature was uncontrolled.

Cough and dyspnoea. The great majority had cough and dyspnoea which improved in varying periods from 24 to 72 hours except those suffering from whooping-cough.

Stools. Stools became normal in two to five days except in one infant who had diarrhoea for six days and required intravenous fluids.

TOTAL DOSE OF THE DRUG. Average $17.5 \mathrm{gm}$. No complications of the drug were observed.

COMPLICATIONS OF THE ILLNESS. Four infants had otitis media on admission and one required mastoidectomy. Two developed otitis media while in hospital. One suffered from measles and two from whooping-cough. One mongoloid defective had jaundice.

POST-MORTEM fINDINGS. Post-mortem examination was obtained in only five of the eleven patients who died. One showed pneumonia, one bronchopneumonia, one bronchopneumonia and left acute otitis media, one pneumonia and empyema, and one bronchopneumonia with right-sided mastoiditis.

\section{SulPhadiaZINE}

GeNERAL FIGURES. There were 15 patients, 11 males and 4 females; 3 were premature and 12 were mature infants. Thirteen suffered from bronchopneumonia and 2 from pneumonia. Of the 15 cases, 7 died ( 46.6 per cent.).

0 to 1 month, $7 ; 3$ deaths ( $42 \cdot 8$ per cent.).

1 to 9 months, 8 ; 4 deaths (50 per cent.).

GeNerAL ASSESSMENT. Severe, 9 with 7 deaths (77.7 per cent.); moderate, 6 with no deaths.

PROGRESS OF THE DISEASE. Duration of pyrexia. Of the survivors four were apyrexial throughout. One was pyrexial for $\mathbf{2 4}$ hours, two for $\mathbf{4 8}$ hours and one for six days. In those who died, two premature infants were apyrexial throughout, one premature infant was pyrexial for 24 hours only, one infant for four days and in three cases the temperature was uncontrolled.

Cough and dyspnoea. In ten improvement occurred in 24 to 72 hours. In one which had whooping-cough dyspnoea improved in 48 hours but cough persisted.

Stools. In those with diarrhoea, stools were normal in one to four days.

TOTAL DOSE OF THE DRUG. Average $15.5 \mathrm{gm}$. No complications of the drug were observed.

COMPLICATIONS OF THE ILLNESS. One had otitis media on admission, one developed it while in hospital and one had congenital heart disease.

POST-MORTEM FINDINGS. Permission for postmortem examination was obtained in six cases with the following results:-

1. Bronchopneumonia, congenital heart disease with subacute infective endocarditis.

2. Bronchopneumonia, pericardial and pleural effusions and right mastoiditis.

3. Pneumonia, bilateral otitis media, patent foramen ovale.

4. Bronchopneumonia, atelectasis and prematurity.
5. Bronchopneumonia and right mastoiditis.

6. Bronchopneumonia and prematurity.

\section{SULPHAPYRIDINE}

General figures. There were 19 cases, eight males and eleven females. All were mature infants. Fifteen suffered from bronchopneumonia and four from pneumonia. Of the 19 cases, six died (31.5 per cent.).

0 to 1 month, $7 ; 3$ deaths ( $42 \cdot 8$ per cent.).

1 to 9 months, $12 ; 2$ deaths ( $16 \cdot 6$ per cent.).

GeNERAL ASSESSMENT. Severe, 10 with 5 deaths (50 per cent.); moderate, 9 with no deaths.

PROGRess OF THE DISEASE. Duration of the pyrexia. Five patients were apyrexial in 24 hours, one in three days, three in four days, four in six days, one in 15 days. In five cases temperature was uncontrolled.

Cough and dyspnoea. These symptoms continued for varying times but on the whole longer than with sulphamezathine and sulphadiazine.

Stools. In those with diarrhoea, stools became normal in two to ten days.

TOTAL DOSE OF THE DRUG. Average $14.2 \mathrm{gm}$.

COMPLICATIONS OF THE DRUG. Four patients were very cyanosed due to the drug and one vomited frequently until the drug was stopped.

COMPLICATIONS OF THE ILLNESS. One patient had bilateral acute otitis media with profuse otorrhoea on admission. Two developed otitis media in hospital and myringotomy was necessary. One of these also developed chicken pox. In one case the pneumonia relapsed and was successfully re-treated. Another patient developed a small abscess on the right shoulder which had to be incised and one was being treated with sulphapyridine for gonorrhoeal ophthalmia when the pneumonia commenced.

POST-MORTEM FINDINGS. Permission for postmortem examination was obtained in four cases with the following results:

1. Bronchopneumonia with pericardial effusion and grossly enlarged heart.

2. Bronchopneumonia.

3. Bronchopneumonia and right acute otitis media.

4. Pneumonia, left upper and lower lobes.

\section{Comment}

TABLE 2

\begin{tabular}{|c|c|c|c|c|c|c|c|c|c|}
\hline \multirow{2}{*}{. } & & \multicolumn{2}{|c|}{$\begin{array}{c}\text { Meza- } \\
\text { thine } \\
35 \text { cases }\end{array}$} & \multicolumn{2}{|c|}{$\begin{array}{l}\text { Thiazole } \\
28 \text { cases }\end{array}$} & \multicolumn{2}{|c|}{$\begin{array}{l}\text { Diazine } \\
15 \text { cases }\end{array}$} & \multicolumn{2}{|c|}{$\begin{array}{l}\text { Pyridine } \\
19 \text { cases }\end{array}$} \\
\hline & & No. & $\begin{array}{l}\text { Per } \\
\text { cent. }\end{array}$ & No. & $\begin{array}{l}\text { Per } \\
\text { cent. }\end{array}$ & No. & $\begin{array}{l}\text { Per } \\
\text { cent. }\end{array}$ & No. & $\begin{array}{l}\text { Per } \\
\text { cent. }\end{array}$ \\
\hline $\begin{array}{l}\text { Premature } \\
\text { Neonates }\end{array}$ & $\begin{array}{l}\ldots \\
\ldots\end{array}$ & $\begin{array}{r}8 \\
14\end{array}$ & $\begin{array}{l}22 \cdot 8 \\
40 \cdot 0\end{array}$ & $\begin{array}{r}3 \\
10\end{array}$ & $\begin{array}{l}10 \cdot 7 \\
35 \cdot 7\end{array}$ & $\begin{array}{l}3 \\
7\end{array}$ & $\begin{array}{l}20 \cdot 0 \\
46 \cdot 6\end{array}$ & $\overline{7}$ & $\overline{36 \cdot 8}$ \\
\hline $\begin{array}{l}\text { Severe .. } \\
\text { Moderate }\end{array}$ & . & $\begin{array}{l}23 \\
12\end{array}$ & $\begin{array}{l}65 \cdot 7 \\
34 \cdot 3\end{array}$ & $\begin{array}{r}20 \\
8\end{array}$ & $\begin{array}{l}71 \cdot 4 \\
28 \cdot 6\end{array}$ & $\begin{array}{l}9 \\
6\end{array}$ & $\begin{array}{l}60 \cdot 0 \\
40 \cdot 0\end{array}$ & $\begin{array}{r}10 \\
9\end{array}$ & $\begin{array}{l}52 \cdot 6 \\
47 \cdot 4\end{array}$ \\
\hline Deaths & $\ldots$ & 9 & $28 \cdot 5$ & 11 & $39 \cdot 2$ & 7 & $46 \cdot 6$ & 6 & $31 \cdot 5$ \\
\hline
\end{tabular}

From table 2 it will be seen that the four groups are not quite equal in severity. Having regard to the factors which influence the severity of the groups from the therapeutic point of view and beginning with the most severe, the groups probably arrange themselves in order of severity as follows - sulphamezathine group, sulphadiazine 
group, sulphathiazole group and sulphapyridine group. It is striking that the lowest death rate occurs in the most severe group, which was treated with sulphamezathine. As it happens the mildest group was treated with sulphapyridine and here the death rate is slightly higher than in the most severe group. In the sulphathiazole group the high incidence of severe cases is to some extent offset by the lower incidence of prematurity and neonates, and in the sulphadiazine group the higher incidence of prematurity and neonates is offset to some extent by the lower incidence of severe cases. Sulphathiazole seems to give rather better results than sulphadiazine, and the lowest death rate among the severe cases is in the sulphamezathine group. From this analysis it would seem justifiable to assess the merits of the various drugs in descending order as follows-sulphamezathine, sulphathiazole, sulphapyridine and sulphadiazine. Under one month the death rate is high with all the drugs, i.e. 40 to 60 per cent. Therefore the difference in the total therapeutic result appears to occur among the older infants. Comparing the average total dose it is found that smaller amounts of sulphamezathine and sulphapyridine are required to achieve their results than is the case with the others. Sulphamezathine was found to be well tolerated, non-toxic and to give rapid and satisfactory results. In the neonatal group four cases displayed a mild cyanosis, which (in three who recovered) continued after the acute phase was over and only ceased when the drug was discontinued. This cyanosis was thought to be due to the drug but is not a contraindication to its use. With sulphathiazole the response seemed to be slower, but no toxic manifestations occurred either with sulphathiazole or with sulphadiazine. Sulphapyridine produced more severe toxic results than the others, four becoming very cyanosed and one vomiting frequently. It was also thought that cough and dyspnoea continued longer than with the other drugs. From this series it seems that sulphamezathine is the drug of choice.

Jennings and Patterson (1942) describe eleven cases, nine of whom were under two years of age, all of whom improved in thirty-six hours and all of whom recovered. One relapsed and was successfully re-treated. They also describe satisfactory response in older children. One infant developed a rash after $7 \mathrm{gm}$. of sulphamezathine and two older children developed rashes, but no other toxic effects were observed. Peters and Easby (1943) describe their experience of sulphamezathine in a group of cases containing 21 patients under two years of age, of whom two died. One child aged two had complete urinary suppression and two others developed 'a curious painless brawny oedema of the whole legs and arms' thought to be due to some circulatory disturbance. Apart from this they report no toxic effects. Experience of the treatment of pneumonia in older subjects with sulphathiazole is described by Gaisford and Whitelaw (1940) who found that the temperature did not fall so rapidly as with sulphapyridine. Greengard, Raycroft and Motel (1941), describe 200 infants treated with sulphapyridine with a 10 per cent. mortality. Before chemotherapy their death rate was 32 per cent. In an addendum to their paper Evans and Gaisford (1938) mention forty cases of bronchopneumonia in children treated with sulphapyridine with two deaths. They also mention two infants who recovered.
Gaisford, Whitelaw and Evans (1939) describe six infants suffering from pneumonia and bronchopneumonia treated with parenteral sulphapyridine soluble, administered intra-muscularly with two deaths.

\section{(2) Parenteral infections}

(b) Bronchitis and upper respiratory infection. In this group there are forty cases and the same sulphonamides were used. Symptoms were as follows: All showed some cough and dyspnoea. Diarrhoea occurred in seven, vomiting in 15 . Pyrexia was present in 27, while 13 were apyrexial.

\section{SUlPHAMEZATHINE}

General figures. There were 17 cases, ten males and seven females, among whom there were no deaths.

General asSESSMEnt. Severe, 5; moderate, 11; mild, 1.

PROGRESS OF THE DISEASE. Duration of pyrexia. Six were apyrexial in 24 hours, four in 48 hours, one in 96 hours, whilst six were apyrexial throughout. Cough and dyspnoea lasted for varying periods. Vomiting ceased in 24 to 96 hours. Only one gave a history of diarrhoea but the stools were found to be normal after admission.

TOTAL DOSE OF THE DRUG. Average $10 \mathrm{gm}$. No complications of the drug were noted.

COMPLICATIONS OF THE ILLNESS. One had bilateral otitis media on admission and four developed this complication from the tenth to twenty-first day in hospital. Four of these required myringotomy. In two cases the otitis media was treated with different sulphonamides-sulphadiazine and sulphathiazole respectively. They all made good recoveries.

\section{SUPHATHIAZOLE}

General figures. There were seven cases, five males and two females and two were premature infants. No deaths occurred.

General asSESSMENT. Severe, 1; moderate, 5; mild, 1.

PROGRESS OF THE DISEASE. Duration of pyrexia. Temperature fell in $\mathbf{2 4}$ hours in three cases, and in 48 hours in one case. Three were apyrexial throughout. Of the five giving a history of vomiting, three did not vomit after admission and two ceased in 24 hours. Of the three with diarrhoea, stools became normal in 24 hours in one case and in 48 hours in two cases. One was slightly dehydrated on admission but this was relieved in 24 hours.

TOTAL DOSE OF THE DRUG. Average $14 \mathrm{gm}$. There were no complications.

Complications OF tHE ILLNESS. One case relapsed on the nineteenth day and was successfully re-treated, the temperature falling in 24 hours on both occasions. One had bilateral otitis media on admission and one developed it on the seventeenth day.

\section{SUlPhADIAZINE}

General figures. There were five cases, two males and three females, of whom one died.

General ASSESSMent. Moderate, 2; mild, 3.

PROGRess OF THE DISEASE. One was apyrexial in 24 hours, one in 48 hours and one in five days. Two were apyrexial throughout. There was nothing noteworthy about the other symptoms. 
TOTAL DOSE OF THE DRUG. Average $16.25 \mathrm{gm}$. No complications were noted.

COMPLICATIONS OF THE ILLNESS. One had a cleft palate and one had a septic finger A third developed bilateral acute otitis media on the twelfth day. This infant, who died, required myringotomy and intravenous fluids.

Post-MORTEM Findings. Pus was found in the right mastoid antrum and in the left middle ear. Further examination was not permitted.

\section{SULPHAPYRIDINE}

GenERAL FIGURES. There were 11 cases, five males and six females, among whom were two premature infants. Two deaths occurred.

General ASSESSMENT. Severe, 5; moderate, 6.

Progress OF THE DISEASE. Four were apyrexial in 24 hours, one in 48 hours, two in 72 hours and one in 96 hours. In one case, a premature infant who died, temperature was uncontrolled. Other symptoms presented no remarkable features.

TOTAL DOSE OF THE DRUG. Average $16 \mathrm{gm}$. The premature infant who died only had $1.0 \mathrm{gm}$. but the other case who died had $13.5 \mathrm{gm}$. There were no complications of the drug.

COMPLiCATIONS OF THE ILLNESS. One case developed otitis media on the sixteenth day. Another who died had left acute otitis media on admission and the right became similarly affected on the sixteenth day. Intravenous therapy and blood transfusions failed to help and ultimately bilateral mastoidectomy was performed when much pus was found in both antra. The pus was found to be sterile. Unfortunately the infant died, and permission for post-mortem examination was refused.

Post-MORTEM FINDINGS. Permission in the case of the premature infant was obtained and the diagnosis of bronchitis and prematurity confirmed.

\section{Comment}

This was on the whole a mild group of cases and it is felt that the great majority would have progressed just as favourably without sulphonamides. There were three deaths, two of them due, not to bronchitis, but to the development of otitis media and mastoiditis. The third was an infant in whom prematurity played as great a part as the bronchitis. Cases of bronchitis and upper respiratory infection, especially the latter, are peculiarly prone to develop otitis media. Eight cases ( 20 per cent.) developed this complication and it seems that the exhibition of sulphonamides has little effect in preventing the onset of this serious complication.

\section{Part III}

\section{(2). Parenteral infections (continued)}

(c) Otitis media and mastoiditis. In this group 97 cases are described and four sulphonamides are used-sulphadiazine, sulphamezathine, sulphathiazole and sulphapyridine. A few cases received no chemotherapy. The group presented symptoms as follows-diarrhoea 72 , vomiting 64 , dehydration 76 , weight loss 85 and pyrexia 67 , with signs of inflammation in the tympanic membranes or otorrhoea in all cases.

\section{SUlPHADIAZINE}

General FIGURES. There were 32 cases, 19 males and 13 females, among whom were 5 premature infants and 27 mature infants. No deaths occurred. Twenty-two were neonates and 10 were older infants.

GenerAl ASSESSMENT. Severe, 12; moderate, 5; mild, 15 .

Progress of THE DISEase. Duration of pyrexia. Fifteen cases were apyrexial throughout. In the remainder the temperature varied from $99^{\circ} \mathrm{F}$ to $103^{\circ} \mathrm{F}$. and lasted on an average three days. In those with diarrhoea stools became normal in an average of 3.8 days. In twelve cases dehydration was overcome by glucose saline by mouth, one received subcutaneous and intramuscular salines and five required continuous intravenous fluid. With the exception of three taken from hospital against advice, all ultimately gained weight. Only one case relapsed and was successfully retreated.

TOTAL DOSE OF THE DRUG. Average $17 \mathrm{gm}$. No complications were noted.

LOCAL TREATMENT. Twenty-eight cases received local treatment with glycerin and carbolic acid drops and a few, when otorrhoea persisted, received spirit drops.

\section{SULPHAMEZATHINE}

General Figures. There were 12 cases, 11 males and one female, who were all mature infants and none was in the neonatal period of life. Of the 12 cases, one died (8.5 per cent.).

General ASSESSMENT. Severe, 7 with 1 death; moderate, 4 ; mild, 1 .

Progress OF THE DISEASE. Vomiting. Of those giving a history of vomiting, two did not vomit after the commencement of the treatment. The others continued to vomit for periods varying from two to six days, average three days.

Diarrhoea. Of those giving a history of diarrhoea the diarrhoea continued for periods varying from two to nine days (average four days) after the commencement of treatment.

Dehydration. This was overcome by fluids by mouth in nine cases. One infant was given subcutaneous salines and the other two continuousintravenous drip salines.

Weight loss. With the exception of the infant who died and one taken home against advice, all ultimately gained weight.

Pyrexia. Two were apyrexial throughout. The remainder had temperatures varying from $100 \cdot 8^{\circ} \mathrm{F}$. to $104 \cdot 5^{\circ} \mathrm{F}$. which continued from two to eight days, average four days.

Relapse. Three cases relapsed and myringotomies became necessary. One of these appeared to have settled without perforation, but later myringotomy became necessary. In the case which died myringotomy was performed and the ears discharged, but the infant did not respond and was thought to be probably suffering from mastoiditis. Unfortunately permission for post-mortem examination was refused.

TOTAL DOSE OF THE DRUg. Average $17 \mathrm{gm}$. No complications were noted.

LOCAL TREATMENT. Glycerin and carbolic acid drops were given in all cases. 


\section{SUlPHATHIAZOLE}

General figures. There were 35 cases, 19 males and 16 females, among whom were three premature infants and 32 mature infants. Of the 35 cases, eight died $(22 \cdot 8$ per cent.).

0 to 1 month, $9 ; 3$ deaths $(33 \cdot 3$ per cent.).

1 to 9 months, $26 ; 5$ deaths $(19 \cdot 2$ per cent.).

GENERAL ASSESSMENT. Severe, 16 with 8 deaths (50 per cent.); moderate, 18 with no deaths; mild, 1 with no deaths.

Progress OF THE DISEASE. Vomiting continued on an average for two days.

Diarrhoea continued for 2 to 21 days (average five days).

Dehydration. This was overcome by fluids by mouth in twenty cases. Fifteen required continuous intravenous drip salines.

Weight loss. Of those who recovered the majority gained weight. One was taken from hospital against advice and some could not be weighed as they suffered from some infectious disease, e.g. whooping-cough.

Pyrexia. Seven were apyrexial throughout and the remainder were pyrexial for one to four days, average $2 \cdot 5$ days.

Relapse. Only one case relapsed and was subsequently successfully treated with penicillin.

TOTAL DOSE OF THE DRUG. Average $16 \mathrm{gm}$. No complications were noted.

LOCAL TREATMENT. Thirty cases had glycerin and carbolic acid drops and local heat.

POST-MORTEM FINDINGS. Unfortunately permission was obtained only in two cases. In one of these pus was found in both middle ears and mastoid cells and severe bronchopneumonia. In the second case much bronchitis was found but the middle ears seemed clear. Myringotomy had released thin pus from the left middle ear in this case and it is possible that chemotherapy had caused resolution of the otitis media. In all the other cases who died myringotomy had released considerable quantities of pus and in one the ears had apparently resolved, but the infant was thought to have died of pemphigus and septicaemia. The two cases upon whom mastoidectomies were performed died. Pus was found in both antra in these cases.

\section{SULPHAPYRIDINE}

General FIGURES. There were six cases, four males and two females. All were mature infants and there were three deaths. There was one neonate which recovered.

Genteral asSESSMENT. Severe, 4 with 3 deaths (75 per cent); moderate, 2.

Progress OF THE DISEASE. Vomiting ceased in 24 to 48 hours in those who recovered.

Diarrhoea continued for two to seven days.

Dehydration. One was not dehydrated. In one dehydration was overcome by fluids by mouth and one required continuous intravenous drip saline.

Weight loss. Those who recovered gained well.

Pyrexia. Two were apyrexial and once ceased to be so after 48 hours.

Relapse. No relapses occurred in those who recovered.

TOTAL DOSE OF THE DRUG. In those who recovered the average was $13 \mathrm{gm}$. No complications of the drug were observed.

LOCAL TREATMENT. All had glycerin and carbolic acid drops and local heat.
Three cases died, all of whom ultimately required myringotomy. Two originally discharged spontaneously after the drug had been begun and improved, but later became ill again when myringotomy was necessary and pus released. These cases had three courses of sulphapyridine with a total dose of $52.5 \mathrm{gm}$. and $34.5 \mathrm{gm}$. respectively, i.e. relapse after apparent recovery occurred. In one case bilateral mastoidectomy was performed and pus found in both antra. No post-mortem examinations were obtained and one of these cases developed severe chicken pox.

\section{No CHEMOTHERAPY}

General Figures. There were twelve cases, five males and seven females, among whom was one premature infant. Two were in the neonatal period, of whom one died. Ten were older infants. Of the twelve cases, two died.

GeNERAL ASSESSMENT. Severe, 4 with 2 deaths (50 per cent.); moderate, 6 ; mild, 2.

PROGRess OF THE DISEASE. Vomiting ceased in one to three days.

Diarrhoea. Four had no diarrhoea after the commencement of treatment. One had diarrhoea for seven days but the others continued with periods of diarrhoea for three to seven weeks, progress being very slow.

Dehyration. All except one received fluids by mouth. Of the two who died one received fluids by mouth and the other continuous intravenous drip saline.

Weight loss. All of those who recovered, except one, gained weight satisfactorily.

Pyrexia. Seven were apyrexial throughout. The others were pyrexial for one to four days, average two days.

LOCAL TREATMENT. Eleven had glycerin and carbolic acid drops and local heat.

Post-MORTEM EXAMinations. Permission for examination was obtained in the two cases who died. In one, a premature infant, from whose ears pus had been obtained by myringotomy, bronchopneumonia and pus in the left middle ear were found. The second case had been admitted with pneumonia which had improved when the otitis media developed. Permission for a complete examination was withheld and only the mastoids were opened. Pus was found in both antra.

\section{Comment}

The difficulties in assessing the value of the sulphonamides used are apparent from a study of tables 3 and 4 . In table 3 it can be seen that from the point of view of the incidence of prematurity the sulphadiazine group is the most severe. From the point of view of the severity of the illness the groups, unfortunately headed by the two smallest groups, fall into the following order-sulphapyridine, sulphamezathine, sulphathiazole, sulphadiazine and the group with no chemotherapy. Although the group with no chemotherapy is the least severe, the results in this group are not so good as in the sulphamezathine and sulphadiazine groups, the former being one of the most severe groups and the latter containing the highest percentage of premature infants. Sulphapyridine gives the worst results of the drug-treated groups. If the first three are 
arranged according to severity and results the following two columns can be obtained.

\section{SEVERITY}

Sulphamezathine

Sulphathiazole

Sulphadiazine
RESULTS

Sulphadiazine

Sulphamezathine

Sulphathiazole
The drug which keeps highest in both columns is sulphamezathine, which would therefore seem to be the most efficacious drug. Sulphadiazine and sulphathiazole take second place. Unfortunately the sulphamezathine group is a small group and this conclusion is probably not justifiable. On the other hand table 4 reveals that in the sulphamezathine group a high proportion of cases required myringotomy after the drug had been given and in no case did the otitis media settle without discharging. In assessing table 4 the stage which the otitis media had reached when treatment was instituted must be kept in mind. For instance, in the sulphathiazole group a large number of myringotomies were performed simultaneously with administration of the drug because there was obviously pus behind the drums when treatment was begun. Nevertheless the sulphathiazole group contains the highest percentage which settled without discharge of pus and the lowest percentage of those which were given a chance to settle and failed to do so without myringotomy. No spontaneous discharge occurred in the sulphathiazole group but these good points are offset by the higher death rate. From this point of view the next most satisfactory drug is sulphadiazine, in which group no deaths occurred. Clinically sulphathiazole seemed to have a good effect on the amount of discharge after the necessary myringotomies had been performed and a similar effect was noticed with sulphapyridine. With sulphadiazine there was much less tendency to relapse than with sulphamezathine and the effect of this drug on the general condition and the tympanic membranes was better than with sulphamezathine. Sulphamezathine seemed to exert an improvement on the toxicity of the infants but its local effect on the drums was less than with sulphathiazole or sulphadiazine. From this analysis it

TABLE 3

\begin{tabular}{|c|c|c|c|c|c|c|c|c|c|c|c|}
\hline & & \multicolumn{2}{|c|}{$\begin{array}{l}\text { Diazine } \\
32 \text { cases }\end{array}$} & \multicolumn{2}{|c|}{$\begin{array}{l}\text { Mezathine } \\
12 \text { cases }\end{array}$} & \multicolumn{2}{|c|}{$\begin{array}{l}\text { Thiazole } \\
35 \text { cases }\end{array}$} & \multicolumn{2}{|c|}{$\begin{array}{l}\text { Pyridine } \\
6 \text { cases }\end{array}$} & \multicolumn{2}{|c|}{$\begin{array}{l}\text { No chemotherapy } \\
12 \text { cases }\end{array}$} \\
\hline & & No. & Per cent. & No. & Per cent. & No. & Per cent. & No. & Per cent. & No. & Per cent. \\
\hline $\begin{array}{l}\text { Premature.. } \\
\text { Mature .. }\end{array}$ & $\begin{array}{l}\ldots \\
\ldots\end{array}$ & $\begin{array}{r}5 \\
27\end{array}$ & $\begin{array}{l}15 \cdot 6 \\
84 \cdot 3\end{array}$ & $\overline{12}$ & $\overline{100 \cdot 0}$ & $\begin{array}{r}3 \\
32\end{array}$ & $\begin{array}{r}8 \cdot 5 \\
91 \cdot 4\end{array}$ & $\overline{6}$ & $100 \cdot 0$ & $\begin{array}{r}1 \\
11\end{array}$ & $\begin{array}{r}8 \cdot 3 \\
91 \cdot 6\end{array}$ \\
\hline $\begin{array}{l}\text { Mild } \\
\text { Moderate ... } \\
\text { Severe } \quad .\end{array}$ & $\begin{array}{l}. \\
\cdots \\
.\end{array}$ & $\begin{array}{r}15 \\
5 \\
12\end{array}$ & $\begin{array}{l}46 \cdot 8 \\
15 \cdot 6 \\
37 \cdot 5\end{array}$ & $\begin{array}{l}1 \\
4 \\
7\end{array}$ & $\begin{array}{r}8 \cdot 3 \\
33 \cdot 3 \\
58 \cdot 3\end{array}$ & $\begin{array}{r}1 \\
18 \\
16\end{array}$ & $\begin{array}{r}2 \cdot 8 \\
51 \cdot 4 \\
45 \cdot 7\end{array}$ & $\begin{array}{c}\overline{2} \\
4\end{array}$ & $\begin{array}{l}\overline{33 \cdot 3} \\
66 \cdot 6\end{array}$ & $\begin{array}{l}2 \\
6 \\
4\end{array}$ & $\begin{array}{l}16 \cdot 6 \\
50 \cdot 0 \\
33 \cdot 3\end{array}$ \\
\hline Deaths & .. & - & - & 1 & $8 \cdot 3$ & 8 & $22 \cdot 8$ & 3 & $50 \cdot 0$ & 2 & $16 \cdot 6$ \\
\hline
\end{tabular}

TABle 4

\begin{tabular}{|c|c|c|c|c|c|c|c|c|c|c|}
\hline \multirow{3}{*}{ Drug } & \multirow{3}{*}{$\begin{array}{c}\text { No } \\
\text { dis- } \\
\text { charge }\end{array}$} & \multicolumn{6}{|c|}{ Aural discharge } & \multirow{3}{*}{$\begin{array}{l}\text { Relapse } \\
\text { rate }\end{array}$} & \multirow{3}{*}{$\begin{array}{c}\text { Mastoid- } \\
\text { ecto- } \\
\text { mies }\end{array}$} & \multirow{3}{*}{ Deaths } \\
\hline & & \multicolumn{3}{|c|}{ Myringotomy } & \multicolumn{3}{|c|}{ Spontaneous discharge } & & & \\
\hline & & $\begin{array}{l}\text { Before } \\
\text { drug }\end{array}$ & $\begin{array}{l}\text { Simul. } \\
\text { with } \\
\text { drug }\end{array}$ & $\begin{array}{l}\text { After } \\
\text { drug }\end{array}$ & $\begin{array}{l}\text { Before } \\
\text { drug }\end{array}$ & $\begin{array}{l}\text { Simul. } \\
\text { with } \\
\text { drug }\end{array}$ & $\begin{array}{l}\text { After } \\
\text { drug }\end{array}$ & & & \\
\hline $\begin{array}{l}\text { Diazine } \ldots \\
\text { (32 cases) }\end{array}$ & $6(18 \cdot 7)$ & $1(3 \cdot 1)$ & $7(21 \cdot 8)$ & $5(15 \cdot 6)$ & $8(25 \cdot 0)$ & $3(9 \cdot 3)$ & $2(6 \cdot 2)$ & $1(3 \cdot 1)$ & $2(6 \cdot 2)$ & - \\
\hline $\begin{array}{l}\text { MEZATHINE } \\
(12 \text { cases })\end{array}$ & - & $1(8 \cdot 3)$ & $2(16 \cdot 6)$ & $7(58 \cdot 3)$ & - & $1(8 \cdot 3)$ & $1(8 \cdot 3)$ & $3(25)$ & $3(25.0)$ & $1(8 \cdot 3)$ \\
\hline $\begin{array}{l}\text { THIAZOLE ... } \\
\text { (35 cases) }\end{array}$ & $7(20 \cdot 0)$ & $3(8 \cdot 5)$ & $21(60 \cdot 0)$ & $4(11 \cdot 2)$ & - & - & - & $1(2 \cdot 8)$ & $2(5 \cdot 7)$ & $8(22 \cdot 8)$ \\
\hline \multirow[t]{2}{*}{$\underset{\text { Pyidine cases) }}{\text { Pyinis }}$} & $1(16 \cdot 6)$ & - & $3(50 \cdot 0)$ & $2(33 \cdot 3)$ & - & - & - & $2(33 \cdot 3)$ & $1(16 \cdot 6)$ & $3(50 \cdot 0)$ \\
\hline & & \multicolumn{3}{|c|}{ Myringotomy } & \multicolumn{3}{|c|}{ Spontaneous discharge } & & & \\
\hline $\begin{array}{l}\text { No CHEMOTHERAPY } \\
\text { (12 cases) }\end{array}$ & $1(8 \cdot 3)$ & \multicolumn{3}{|c|}{$11(91 \cdot 6)$} & \multicolumn{3}{|c|}{ - } & $2(16 \cdot 6)$ & - & $2(16 \cdot 6)$ \\
\hline
\end{tabular}


seems that the best drugs to employ in otitis media of infancy are sulphathiazole and sulphadiazine.

There are few references describing specifically the effect of sulphonamides in otitis media and mastoiditis in infancy. Burns and Gunn (1944) describe four cases of gastroenteritis associated with otitis media and mastoiditis treated with sulphonamides, one, which recovered, with sulphathiazole and three, one of whom died, with sulphamezathine. These cases also received penicillin either locally or systemically so that it is difficult to assess the part played by the sulphonamides. Leathart (1943) mentions the use of sulphonamides but gives no details or impressions. Patterson and Stewart Smith (1944) say that many of their cases were treated with 'adequate doses of one or other of the sulphonamide drugs' but no effect was observed. In a series of 124 cases of infantile diarrhoea and vomiting Alexander and Eiser (1944) found 60 cases of otitis media and in describing their treatment say that after search for foci of parenteral infection 'sulphonamides, chiefly sulphathiazole, were given in large doses' but again no details or impressions of the efficacy of this treatment are given.

Another interesting point deserves mention. Some otologists, for example Dingley (1944), find that the administration of sulphonamides to older children and adults may lead to masking of serious intracranial complications with disastrous results. This fear need not arise in connexion with infantile otitis media and mastoiditis because intracranial complications are rare. This has been the experience of Southby (1924), and Dodds (1931), describing a case of infantile mastoiditis which developed purulent meningitis, also comments upon the rarity of intracranial complications. Patterson and Stewart Smith (1944) state that 'subperiosteal abscess should be, and in fact is, a very common complication of mastoiditis in babies' and that 'extradural abscess and meningitis are ever present dangers, and not rare complications, of acute otitis media in infants.' This is not in keeping with the experience of the present writers. Patterson and Stewart Smith also open their description of their investigation by using the term 'mastoid' to include the middle ear and mastoid antrum and state that under the age of two years there is no sharp division between them and the mastoid cells are undeveloped. We strongly disagree with this view, holding that otitis media can undoubtedly occur alone and unaccompanied by mastoiditis in infancy. Infantile mastoiditis is probably uninfluenced by sulphonamides but acute otitis media can certainly be influenced, although not to the extent we should wish.

\section{(2) Parenteral infections}

(d) Pyelitis. There were seven cases in this group, one male and six females. All were mature and one was in the neonatal period. One death occurred. Symptoms were as follows-vomiting occurred in three cases, diarrhoea in all the cases, dehydration in five, pyrexia in five varying from $100 \cdot 2^{\circ}$ to $104^{\circ} \mathrm{F}$., weight loss in three cases. Three cases were judged severe, two moderate and two mild. All were B. coli infections. Sulphapyridine, sulphathiazole, sulphadiazine and sulphamezathine were employed and one case received no chemotherapy.

\section{Progress of The disease}

(1) Case treated with Sulphapyridine. This was a case of intussusception which developed pyelitis during the third week in hospital. Urinalysis showed albumin and pus (20 cells per field). This case made an uneventful recovery, having received $16 \mathrm{gm}$. of the drug.

(2) CaSes tReated WITH SUlphathiazole. (a) This infant was admitted to hospital with pyelitis. Urinalysis showed albumin and pus (110 cells per field). This infant made a good recovery, having had $22 \mathrm{gm}$. of the drug.

(b) This infant was admitted as a feeding error and in the third week in hospital developed pyelitis. With the first course of sulphathiazole improvement and gain in weight occurred but the urine still contained pus. Relapse followed and a second course was commenced but ultimately the infant died. Urinalysis showed albumin and pus (20 to 25 cells per field persistently), hyaline and granular casts. The blood urea was $49 \mathrm{mgm}$. per cent. The first course consisted of $28 \mathrm{gm}$. of the drug, but on the second occasion the infant only survived long enough to have $7 \mathrm{gm}$.

Post-mortem findings. Pus was found in the pelves of both kidneys. There were no congenital malformations.

(3) CASE TREATED With SUlphamezathine. This infant, who was admitted with pyelitis, was very ill and dehydrated and required a continuous intravenous drip saline. Urinalysis-albumin and pus ( 20 cells per field) and organisms were still present in the urine after the drug was stopped. This infant recovered, having had $18 \mathrm{gm}$. of the drug.

(4) CASE TREATED WITH SULPHATHIAZOLE AND SULPHADIAZINE. This infant was admitted with bilateral acute otitis media and developed pyelitis during the third week in hospital. A course of sulphathiazole was given but pus remained in the urine although improvement and gain in weight were satisfactory. Relapse then occurred and a course of sulphadiazine was given, after which the urinary infection resolved rapidly but the urine was much less heavily infected than during the sulphathiazole course. Urinalysis, during and after sulphathiazole, showed a considerable quantity of albumin and pus (180 to 250 cells per field) and at the commencement of the sulphadiazine course, a trace of albumin and pus ( 30 cells per field). Blood urea at commencement of the second course was $42 \mathrm{mgm}$. per cent. This infant made a good recovery, having had $19 \mathrm{gm}$. of sulphathiazole and $20 \mathrm{gm}$. of sulphadiazine.

(5) CASE TREATED WITH SUlPHAMEZATHINE AND SULPHATHIAZOLE. This infant was admitted with pyelitis for which a course of sulphamezathine was given. Although improvement and gain in weight occurred, pus remained in the urine and relapse occurred during the fourth week in hospital when a course of sulphathiazole was given. Urinalysis showed albumin and pus ( 20 to 30 cells per field). Recovery eventually took place, the infant having had $20 \mathrm{gm}$. of sulphathiazole and $21 \mathrm{gm}$. of sulphamezathine.

(6) CASE TREATED WITH SODIUM CITRATE AND No SULPHONAMIDE. This infant was admitted as a case of feeding error and great difficulty was experienced in finding a suitable feed. Urine examination was negative shortly after admission. During the eighth week in hospital pyelitis developed 
and 5 grains sodium citrate with 5 grains sodium bicarbonate were administered four-hourly for nine days. Urinalysis showed albumin and pus (40 cells per field). With this treatment the urine cleared in six days.

\section{Comment}

Owing to the small number of cases it is difficult to compare the different sulphonamides. The only case treated with sulphadiazine made a rapid recovery although there had been a severe infection previously treated unsuccessfully with sulphathiazole. On the other hand the case treated with alkalies alone made an equally rapid recovery. Three cases relapsed and in these the urine had never cleared completely. Although it is not always possible to obtain a daily specimen in infants, some indication of the efficacy of these drugs may be obtained by comparing the times taken for the urine to become normal. With sulphapyridine this took seven days. Sulphathiazole was used on four occasions; the urine became normal in four and eight days respectively in two of the cases but was unaffected in the other two. With sulphadiazine the urine became clear in eight days but was possibly helped by the previous course of sulphathiazole. Sulphamezathine was used on two occasions and in one the urine took thirty-two days to become clear and in the other it was unaffected. The urine cleared in six days in the case treated with alkalies only. These results are inconclusive and further observation is necessary. Burns and Gunn (1944) report a case of B. coli pyelitis which responded well to sulphathiazole.

\section{(2) Parenteral infections}

(e) Skin sepsis. This group contains a small number of cases of skin sepsis, 22 in all.

\section{SUlPHADIAZINE}

This group contains six cases suffering from various forms of skin sepsis, two premature infants and four mature infants of whom one lost weight and five were stationary. Four were pyrexial for one to six days. All recovered and the average amount of sulphadiazine given was $15 \mathrm{gm}$. Two were judged severe, one moderate and three mild.

\section{DESCRIPTION OF CASES}

(1) Cellulitis of abdomen and pubis-very satisfactory response.

(2) Abscess of chin and spreading cellulitisapparently settled then recurred and had to be incised.

(3) Cellulitis of cheek-ultimately settled but response poor.

(4) Cellulitis of cheek-satisfactory response.

(5) Umbilical sepsis-satisfactory response.

(6) Submaxillary abscess-no effect, required incission later.

\section{SulPhathiazole}

There are five cases of skin sepsis in this group, which contains two premature infants and three mature infants. Two lost weight, two were stationary and one continued to gain. Four were pyrexial and in the two premature infants this was uncontrolled. In the other two cases temperature con- tinued five and twelve days respectively. The two premature infants died. Two received two courses of the drug and the average amount given was $13 \mathrm{gm}$. Four were judged severe and one moderate.

\section{DESCRIPTION OF CASES}

(1) Cellulitis of face-responded well, relapsed and was successfully retreated.

(2) Multiple septic spots-these occurred on abdomen and legs and one had to be incised -no response, died.

(3) Multiple septic spots with surrounding inflammation-no response, died.

(4) Abscess of wrist and multiple septic spots (Staph. aureus) - abscess was incised and the drug exerted some effect.

(5) Abscess of foot (Staph. aureus)-incisions were carried out and two courses of the drug given-response poor.

Post-MORTEM FINDINGS. Permission was obtained in one case which died. The sepsis seemed to be healing but the lungs showed much bronchitis.

\section{SULPHONAMIDE CREAM}

The cases in this group were treated with sulphonamide cream (5 per cent. sulphanilamide) applied locally. Five also had small amounts of sulphadiazine by mouth. The group consists of eleven infants among whom were three premature infants. Four lost no weight, three were stationary, two lost weight and two became too ill to be weighed. Only two were pyrexial, uncontrolled in one who died and lasting four days in the other. Of the eleven cases four died, two of these being premature infants. Three were judged severe, four moderate and four mild.

\section{DESCRIPTION OF CASES}

Seven were thought to be pemphigus and in five of these staphylococcus aureus was grown from the blebs. There was one death, a premature infant. The remaining four were cases of septic spots affecting mainly the face and scalp. One also had right mastitis which required incision. There were three deaths, one a premature infant. Staphylococcus was grown in two of these cases. In the pemphigus group the response was good, the condition being much improved in two to four days and healed in six to thirteen days. In the case which died the eruption was extensive and no apparent effect took place. It will be noticed that only three cases were considered severe although four died. In the remaining infant who died the skin sepsis was mild and as post-mortem examination was refused the exact cause of death is not known.

Post-Mortem findings. Permission was obtained only in one case, the pemphigus who died, In addition to the pemphigus and prematurity bronchopneumonia affecting both lower lobes was found.

\section{Comment}

In the sulphadiazine group a satisfactory response took place when there was no pus formation and when discharge of pus was free. But in the presence of an actual abscess no response was observed. The sulphathiazole group was more severe, but nevertheless the response was not so good as with 
sulphadiazine. The local treatment of pemphigus with sulphonamide cream is usually very satisfactory but in the scalp type of infection described the response was poor. Troup and White (1939) described one case of pemphigus, treated with sulphapyridine by mouth, which was cured in five days.

\section{Discussion}

In addition to the comments at the end of each section, certain general considerations deserve mention. The success of treatment depends partly upon accurate diagnosis, and the difficulties of diagnosis in infancy are well known. In attempting to assess the results of treatment the attitude of the clinician with regard to the interpretation of clinical signs exerts a great influence. Parenteral infection is common and is responsible for many symptoms which have hitherto been ascribed to quite other causes. The term ' gastroenteritis' is often used incorrectly, since evidence of parenteral infection can so often be found; the main difficulty in diagnosis is the crudeness of methods of clinical examination. We believe that certain forms of parenteral infection give rise to a symptomatic diarrhoea and vomiting with accompanying dehydration. Others take the view that the illness begins as an enteral infection of obscure etiology and that parenteral infection is a secondary phenomenon. In such cases, e.g. otitis media and mastoiditis, the type of treatment, and therefore its success or failure, depends upon which of these views is the correct one. It may be suggested that the figures described in the present series constitute a strong argument against the parenteral theory of etiology (see table 5). Assuming for the purpose of discussion that the parenteral theory is the true one, why is the incidence of diarrhoea and vomiting in the pneumonia and bronchitis groups so much less than in the others? This is a difficult question to answer and various factors are involved. (1) The general state of health of the infant at the time when it is assailed by the infection is of great importance. (2) Infants, no less than adults, show individual differences and some manifest greater hydrolability than others. As Alexander and Eiser (1944) put it, 'Quite often the whole clinical picture is most suggestive of an upset caused by some trigger mechanism setting up the disproportionately violent reaction of diarrhoea and vomiting which eventually marches on its way to a fatal outcome, regardless of the triviality of the first provoking factor.' In other words the trigger is more easily pressed in some than in others. (3) Diarrhoea and vomiting are commoner in some infections than in others and this seems to depend on the site of the infection. The more 'enclosed', if such an expression can be used, the infection is the more likely are these symptoms to occur, e.g. otitis media, mastoiditis and pyelitis. These theories may seem rather far-fetched but no more so than to maintain, in spite of persistently negative pathological and bacteriological findings in the gastrointestinal tract, that gastroenteritis is due to some enteral infection which has so far eluded detection. The problem is by no means settled and in assessing the results described this background must be kept in mind. The subject is worthy of much further investigation.

TABLE 5

\begin{tabular}{|c|c|c|}
\hline & $\begin{array}{c}\text { Diarrhoea } \\
\text { (percentage) }\end{array}$ & $\begin{array}{c}\text { Vomiting } \\
\text { (percentage) }\end{array}$ \\
\hline Neonatal gastroenteritis .. & $96 \cdot 8$ & $57 \cdot 8$ \\
\hline $\begin{array}{ccc}\text { Gastroenteritis } & \text { in } & \text { older } \\
\text { infants } \ldots & \ldots & \ldots\end{array}$ & $100 \cdot 0$ & $91 \cdot 6$ \\
\hline $\begin{array}{cl}\text { Pneumonia and } & \text { broncho- } \\
\text { pneumonia } & \ldots\end{array}$ & $28 \cdot 8$ & $29 \cdot 8$ \\
\hline $\begin{array}{l}\text { Bronchitis and upper re- } \\
\text { spiratory infection }\end{array}$ & $17 \cdot 5$ & $37 \cdot 5$ \\
\hline Otitis media and mastoiditis & $74 \cdot 2$ & $65 \cdot 9$ \\
\hline Pyelitis & $100 \cdot 0$ & $42 \cdot 8$ \\
\hline
\end{tabular}

The above arguments may apply with equal cogency to neonatal gastroenteritis, which many regard as a separate clinical entity. In the majority of the deaths in this group evidence of parenteral infection was found and it is possible that there is no real difference between the so-called neonatal gastroenteritis and gastroenteritis in older infants. Possibly the latest theory, that of a virus infection, will disprove this suggestion. The majority of virus infections are unaffected by the sulphonamides and possibly this may be an explanation of the indifferent results obtained in the present series of neonatal gastroenteritis by chemotherapy. The position of the staphylococcus aureus and organisms of the colon bacillus group in the neonatal period calls for further investigation.

Cooper, Zucker and Wagoner (1941) describe the use of sulphathiazole in acute diarrhoea and dysentery in infants and children. Their series of 123 cases contains 79 under one year. The stools of 59 (47.9 per cent.) of the 123 patients were positive for S. paradysenteriae Flexner and Sonne, and they found that sulphathiazole was of therapeutic value in those whose stools were positive but of no effect in the negative ones. No such cases were found in the present series and therefore this use of sulphathiazole has not been investigated.

The latest drug, sulphamerazine, has not yet been tried by us. In our opinion, if the infantile death rate is to be lowered, a concentrated attack upon parenteral infection is of the first importance.

\section{Conclusions}

(1) A description is given of 415 infants, suffering from various infections, the majority of patients being treated with drugs of the sulphonamide group. On the whole these drugs are well tolerated by infants.

(2) Sulphapyridine tends to cause cyanosis and vomiting. Cyanosis of mild degree but no vomiting 
may also occur with sulphamezathine. Oedema occasionally occurs with sulphaguanidine and sulphasuxidine and the latter drug may also cause an increased tendency to haemorrhage.

(3) In neonatal gastroenteritis the total death rate may be reduced by the use of sulphaguanidine or sulphasuxidine but the treatment must be started early, since in severely ill cases these drugs appear to exert little effect.

(4) Sulphaguanidine and sulphasuxidine probably have little effect in gastroenteritis of older infants.

(5) In pneumonia and bronchopneumonia sulphamezathine is the drug of choice.

(6) Sulphamezathine, sulphathiazole, sulphadiazine and sulphapyridine do not produce striking results in upper respiratory infection and bronchitis. They exert little effect in preventing the development of otitis media.

(7) When otitis media occurs alone, as it often does, the sulphonamides (particularly sulphathiazole and sulphadiazine), constitute a therapeutic advance but not as great an advance as could be wished. It is felt that once mastoiditis has supervened, sulphonamides will not influence the progress of the disease.

(8) The series of pyelitis cases is too small to justify conclusions but an equally good result was obtained with sodium citrate mixture alone as with any of the sulphonamides used.

(9) Cellulitis, unaccompanied by pus formation, can be successfully treated with sulphadiazine and sulphathiazole. The local treatment of pemphigus with sulphonamide cream is very satisfactory.

Thanks are due to Dr. W. E. Crosbie, Medical Superintendent, Alder Hey Children's Hospital, and
Dr. H. H. Macwilliam, Medical Superintendent, Walton Hospital, Liverpool, for permission to publish this paper and to Prof. N. B. Capon for advice and criticism.

\section{REFERENCES}

Alexander, M. B., and Eiser, Y. (1944). Brit. med. J., $2,425$.

Burns, M. B., and Gunn, W. (1944). Ibid., 178.

Collis, W. R. F. (1943). Irish J. med. Sci., No. 212, 362.

Cooper, M. L., Zucker, R. L., and Wagoner, S. (1941). $J$. Amer. med. Ass., 117, 1520.

Craig, W. S. (1936). Lancet, $2,68$.

Dingley, A. R. (1944). Brit. med. J., 1, 747.

Dodds, G. H. (1931). Arch. Dis. Childh., 6, 71.

Evans, G. M., and Gaisford, W. F. (1938). Lancet, 2, 14.

Field, C. E., MacCarthy, D., and Wyllie, W. G. (1943). Brit. med. J., 1, 371.

Gaisford, W. F., Evans, G. M., and Whitelaw, W. (1939). Lancet, $2,69$.

Gaisford, W.F. and Whitelaw, W. (1940). Lancet, 2, 451.

Greengard, J., Raycroft, W. B., and Motel (1941). Ibid. (annotation), 2, 806.

Gunn, W. (1943a). Brit. med. J., 1, 485. (1943b). Brit. J. Child. Dis., 41, 1.

Henderson, J. L. (1943). Brit. med. J., 1, 410.

Jennings, P. A., and Patterson, W. H. (1942). Lancet, 2, 308.

Leathart, P. W. (1943). Brit. med. J., 2, 168.

Lewes, D. S. (1943). Ibid., 815.

Macgregor, A. R. (1939). Arch. Dis. Childh., 14, 323.

McSweeney, J. (1942). Annual Report, Cork Street Hosp., Dublin, 21.

Medical Research Council, War Memorandum, No. 10.

Ormiston, G. (1941). Lancet, 2, 588.

Patterson, W. H., and Stewart Smith, G. (1944). Brit. med. J., 2, 659.

Peters, B. A., and Easby, M. L. (1943). Ibid., 2, 230.

Southby, R. (1924). Med. J. Aust., 1, 410.

Troup, A. G., and White, R. M. (1939). Lancet, 2, 1367.

Twyman, A. H., and Horton, G. R. (1943). J. Amer med. Ass., 123, 138. 